\title{
3. Contending theories of European foreign policy integration
}

\author{
Anna Michalski
}

\section{EUROPEAN INTEGRATION AND THE STUDY OF EUROPEAN FOREIGN POLICY}

European integration has confounded scholars since the first steps towards the European Coal and Steel Community (ECSC) were taken in the early 1950s. The earliest theoretical accounts of the efforts of Western European political and economic elites to deal with the internal and external security dilemmas besetting Europe after the Second World War were written by international relations scholars from the United States (US). The main explanatory tenets presented - intergovernmentalism and neofunctionalism - developed in different directions depending on the scholars' views on the nature of the international system, the weight accorded to domestic versus international sources of influence, and the role of the nation-state in relation to the newly created institutions on the European level. The early integration theories were primarily interested in whether the political processes in Europe would result in a successful creation of a political union along federal lines or as a looser community of states. This empirical and conceptual focus on integration meant that scholars restricted their observations to the foreign policy activities of the member states of the European Community (EC) while they negotiated European treaties and agreements regarding EC policy regimes, largely ignoring the emerging relationships between the $\mathrm{EC}$ and third countries. At any rate, in the first four decades, the EC was mostly concerned with setting up an internal market and attendant policies, a focus that explains why these activities fell outside the scope of international politics. Over time, European studies became a field of its own, incorporating comparative politics, international relations and public policy. Scholarly interest in the European Union's (EU) external activities increased after the Maastricht Treaty in 1993 turned the modest informal consultations among national foreign ministers into the Common Foreign and Security Policy (CFSP). Although the policy remit and the strategic orientation of the CFSP remained uncertain for some time, the 
existence of foreign policy on the European level led to scholarly attempts to conceptualize its nature and therefore theorize the EU as an international actor in its own right.

With a special focus on foreign and security policy, this chapter reviews some of the most prominent theoretical approaches to European integration - realist (intergovernmental), liberal (neofunctional), and constructivist (ideational) - to shed light on their epistemological orientations and opposing perspectives about security, power, institutions, norms and modes of governance. These theoretical approaches have evolved, sometimes in response to the constitutional development of the EU and at other times as a result of a reassessment of their underlying tenets. Most theoretical approaches overlap in significant ways, sharing a few core assumptions. Some, but not all, have been developed specifically to understand the patterns of European integration; and some have borrowed from adjacent fields. Research on European foreign and security policy has evolved significantly since the early days of the European Political Cooperation (EPC) and the establishment of the Common Foreign and Security Policy (CFSP), and today constitutes a vibrant, fast-evolving academic field.

\section{REALISM, INTERGOVERNMENTALISM AND THE STUDY OF EUROPEAN INTEGRATION}

Realism is often considered ground zero for international relations (IR) theory, drawing on the classic works of Thomas Hobbes (anarchy and the state), Machiavelli (statecraft) and Thucydides (the security dilemma), as well as scholars from the twentieth century such as E.H. Carr, Hans Morgenthau and Henry Kissinger, who focused on the principles of international politics, diplomacy and foreign policy. Central to classic realism is the preoccupation with the distribution of power in the anarchical international system. With origins in international law and diplomacy, Morgenthau (1948) advanced the influential principle of political realism, arguing that politics should be conducted on the basis of universal laws, not idealism or ideology, and be grounded in knowledge that human beings are by their nature selfish, and motivated by survival. In the second half of the 1900s, internal criticism levelled against classical realism's penchant for historicism and (legal) philosophy gave rise to neorealism, spearheaded by Kenneth Waltz (1979), who sought to inject a stronger dose of parsimony and systematic investigation into the study of IR in the era of nuclear weapons. Neorealism assumes that international systems and the interaction of states are shaped by their search for security and fulfilment of state interests related to relative gains and zero-sum games. Parsimony requires the following analytical assumptions: an international system that is material in nature; actors who are functionally equal; and actors who rationally 
calculate the power of the resources at their disposal. From this perspective, power rivalries are seen as unavoidable, and give rise to polarities where small states in pursuit of security will attempt to balance or bandwagon vis-à-vis great powers.

Given realism's pessimistic take on cooperation and integration among states, along with the ephemeral nature of state commitments and international institutions, little notice was taken of the emergence of the EC in the early 1950s. For realists, the US support and encouragement of Western European countries to establish their collective political and economic influence were motivated by the US desire to counteract the Soviet Union's post-war influence in Europe. The realist balance-of-power assumption was also applied to understanding the way Western European states chose to deal with the continent's century-old security dilemma, by including West Germany in the EC as a way to find a permanent solution to the balancing of Germany, a restive, central continental power. In this light, it is revealing that John Mearsheimer (1990), who coined offensive (neo)realism, argued in a famous article in 1990 that the reunification of Germany and the demise of the Soviet Union in the early 1990s, which spelled the end to superpower equilibrium in Europe, would lead to a new war because the balance of power among the EU member states would become unstable and old rivalries would be reignited. Because of its basic tenets of presumed behaviour of states and the nature of the international system, neorealism is an unlikely contender as a theoretically informed explanation for the development of the $\mathrm{EU}$, let alone the emergence of the CFSP (Reichwein, 2015). Neorealism has even been described as a 'theory of non-integration', due to its inability to assess the durable commitments of states and the role of institutions with autonomous, albeit circumscribed, powers - including the EU (Wæver, 1995).

Some strands of realism, however, have been used to investigate the premises of European integration, often with a focus on the behaviour of EU member states and their representatives in EU institutions. Although most mainstream realists minimized the intricacies of the negotiations surrounding the creation of the EC in the 1950s and 1960s, Stanley Hoffmann criticized neofunctionalism for its assumption of an unrelenting desire to integrate Europe through functional spillover between policy areas and through a gradual shift in loyalty of the elite towards a new political centre in Europe. Hoffmann was moved by the refusal of the President Charles de Gaulle in 1965 to accept an extension of majority voting in the Council of Ministers, provoking the walk-out of the French representatives in the Council and the 'crisis of the empty chair'. Realists such as Hoffmann (1966) predicted that the member states, and particularly the large ones, would set limits for how far common policy-making would be allowed to advance. That is, rather than becoming obsolete, the nation-state was asserting its control over European 
integration. Accession of sceptic-leaning countries (Denmark and the UK) in the 1970s further accentuated the role of member state governments as gatekeepers of sovereignty, effectively setting the limits of integration. British scholars such as Paul Taylor (1983) refuted the idea that European integration would result in a federal state, as he believed the challenges to sovereignty had been successfully resisted and that the EC's central institutions had failed to make supranational governance permanent.

More recently, neoclassical realists have again applied the central tenets of realism - that is, balance of power, the primacy of the state, and the anarchical international system - to address some intractable challenges of the EU. Both Sebastian Rosato (2011) and Adrian Hyde-Price (2006) emphasize that security issues in Europe during the Cold War drove European integration, as EU member states needed a common framework to balance the superpower rivalry in Europe. Above all, however, the EU and, by extension the CFSP, in their view constitute the structures through which the member states can regulate the distribution of power among them and find a common platform to maximize their considerable weight in global economic affairs. Interestingly, Hyde-Price advances an important critique against the social constructivist argument of the EU as a normative power, by pointing to the significance of the international environment and the systemic pressures that form what is possible for any actor, especially a collective actor such as the EU, while simultaneously emphasizing the constructivist misconception of power, which wrongly couches coercive economic measures as instruments of soft power. In his view, if member states are serious about the EU becoming an effective and coherent international actor, capable of looking after European interests and security on the international scene, they 'must shed some of their lingering illusions about the virtue and efficacy of the EU security strategy based primarily on "soft power" and moral suasion' (Hyde-Price, 2012, p. 18).

With classical realists and neorealists being largely uninterested in the complex processes underlying the creation of the EC, and intergovernmentalists being satisfied with noting that member states remain firmly in the driving seat of integration, liberal intergovernmentalism (LI) emerged in the intersection between liberal theory and intergovernmental perspectives. LI is primarily associated with Andrew Moravcsik (1993, 1997, 1998, 2004) and his continuous scholarship on the EU, ranging from the negotiations to set up the ECSC, the Single European Act and the Maastricht Treaty, to questions about the democratic legitimacy of the EU. Although LI is primarily a framework for explaining the political, economic and social drivers of integration, its basic premises are also valid for understanding European foreign and security policy. The theory earned its liberal epithet by arguing that national interests are derived primarily from domestic socio-economic sources aggregated on the national level. Such interests form the negotiation positions of states on the 
European level, which they defend in negotiations on common political frameworks and policies. Likewise, according to Moravcsik, member states are ready to pool (not transfer) sovereignty to EU institutions on a non-permanent basis as these powers may be rescinded. However, LI adopts something close to a realist position by arguing that EU institutions have no or little authority to act within a set of limited powers. Nonetheless, LI leans more towards neoliberal IR theory, as it emphasizes the role of institutions in overseeing the commitments entered into by the member states in order to minimize information asymmetry and transaction costs of cooperation. LI fell out of fashion as the EU deepened its remit in the early 2000s regarding, for example, home affairs and foreign and security policy, areas that are outside the realm of socio-economic policy. However, the importance of domestic preferences and national political, social and economic constituencies in determining member state interest vis-à-vis the EU still remains central to the study of European integration.

In recent years, new intergovernmentalism (Bickerton et al., 2015) has emerged as a modernized approach to the growing executive governance in the hands of EU member states, as it emphasizes the role played by national governments seeking ways to govern new policy areas on the European level. More concretely, new intergovernmentalism helps explain the specific form of collective governance practised among the heads of state and government in the European Council, as it addresses the challenges with monetary policy, foreign and security policy, justice and home affairs. However, the elevation of the leadership of the European Council has taken place without downgrading the role of the supranational institutions: the European Commission and the European Parliament. Both these institutions have accommodated the collective leadership provided by the European Council. In addition, the intense cooperation among national governments and their representatives in new specialized bodies (for example, the European Central Bank, Frontex and Europol) contributes to this novel form of state transformation, which conforms neither to classic intergovernmental cooperation nor to federalization of member states into a European state (Bickerton, 2012).

\section{LIBERAL INTERNATIONAL RELATIONS THEORY: SECURITY COMMUNITIES AND NEOFUNCTIONALISM}

After the Second World War, political scientists in the liberal IR tradition were preoccupied with the question of how to permanently change interstate relations to make them more cooperative, and how to equip states to better handle competition and resurging conflict. Karl Deutsch (Deutsch et al., 1957) was among the first to coin the concept 'security communities', to describe 
regions where the relations between states had become so intertwined that war and large-scale conflict among them was unthinkable. According to Deutsch, security communities take two forms: amalgamated and pluralistic. Amalgamated states give away many important aspects of their sovereignty to a supranational entity; whereas pluralistic states retain most of their sovereignty, despite transferring formal competences to a supranational entity. The concept of pluralistic security communities builds on the premise that states can share a sense of belonging to a community in which members share common goals, show solidarity and behave in a predictable manner towards each other. These conditions create trust among the members of the security community, a necessary condition for solving issues related to socio-economic competition. Deutsch regards the North Atlantic area in the late 1950s as a potential pluralistic security community, but accorded less importance to the role of regional organizations and their institutions in their quest to create the necessary level of trust. Rather, he believes integration is best served through the establishment of multiple channels of communication, social contacts and economic transactions. The importance of shared norms and socialization in collective identity formation present in security communities has been further investigated by scholars who use the constructivist tradition to frame discussions about security communities (Adler and Barnett, 1998).

The founder of the neofunctionalist school, Ernst Haas, shared liberal IR theory's focus on the political, strategic, economic and social conditions necessary to maintain peace among states seemingly locked in endless strife and conflict. Haas's views were also inspired by David Mitrany's functionalist approach to international politics, which refutes the idealist visions of world governance. Mitrany assigns international organizations with the responsibility of securing peaceful international relations by engaging national governments to address functionally defined issues on the basis of practical politics (Mitrany, 1943). Haas describes his neofunctional approach in The Uniting of Europe (Haas, 1958) and Beyond the Nation-State (Haas, 1964), that investigate the creation of the ECSC and the early evolution of the EC. Haas's ambition was empirical as he set out to explore the motivation of national governments in Western Europe to unite as a supranational entity. Haas recognized the dynamics of unintended consequences generated by intergovernmental agreements prescribing solutions to problems in well-defined policy areas. Unlike neorealism's attempt to formulate law-like propositions of state interaction, neofunctionalism proposes a theoretical framework that explains empirically observable patterns of cooperation and integration in functional areas. Therefore, the success of neofunctionalism as a theory of European integration resides in its ability to identify the practices of cooperation among officials involved in the making of European policy, and to explain the integration dynamics that resulted in spillover between policy areas. 
In his study of the ECSC and the EC, Haas established that integration dynamics emerged in Western Europe through the founding treaties and other intergovernmental agreements established in policy areas where little political resistance was expected. These agreements mobilized interest organizations and national governmental experts who saw the potential to deal with the challenge of socio-economic modernization through cooperation. Functional integration necessitated the creation of administrative bodies, whether in the form of the High Authority of the ECSC or the European Commission of the $\mathrm{EC}$, to implement the decisions taken and to steer the policy-making process. By the force of their mandate to act in the overall European interests, they tasked themselves with proposing technocratic, non-ideological solutions to policy problems. The dynamic that emerged from this process led to spillover of policy areas by the force of the functional interest of issue-based associations and the supranational bodies seeking to deepen integration and extend into new areas. Although neofunctionalism did not deny that integration may result in political tensions among national governments, it concerned itself mainly with the bureaucratic, expert-oriented and executive dimensions of policy-making. Therefore, it avoided or downplayed the political dimension of integration and did not consider whether the spillover dynamics would go beyond the national governments, which were eager to remain in control of the decision-making process and to sanction the transfer of competences to supranational institutions in new policy areas. Although national governments retained a measure of sovereignty, supranational institutions, in particular, the European Commission and the European Court of Justice, acted as norm entrepreneurs and became increasingly autonomous as they expanded the remit of their original mandate set by the treaties (Schmitter, 2005).

With the deepening of European integration and the completion of the internal market, an updated version of neofunctionalism was proposed by Wayne Sandholtz and Alec Stone Sweet (1998, 2018). They refined Haas's approach by conceptualizing the feedback loops of integration and specifying the conditions in which these take place along with the roles of supranational organizations and societal actors. In short, Sandholtz and Stone Sweet (2018) posit that successful integration must include the following three elements: a transnational society comprised by actors with transnational goals; a supranational organization with autonomous capacities to govern specific policy areas; and a system of rules based on supranational governance. The interaction of these elements gives rise to functional demands and translates into calls for pro-integrationist pressure on national governments, which activate the European Commission and the European Court of Justice to expand the policy remit of the EU. This updated neofunctionalism draws attention to the pressure from societal actors for more supranational rule-making, and refines the governance of these regimes. In addition, it puts more emphasis on the demands of 
actors, including national governments; a dynamic that is unlike the functional spillover between policy areas driven by a seemingly automatic logic. In these aspects, the updated approach brings the causal dynamics more to the forefront than the original version of neofunctionalism, and encounters fewer problems explaining the dynamic interaction of member states in these processes.

Given its character, neofunctionalism in its original version did not consider whether integration would move into the realm of foreign and security policy. As primarily an approach to understanding the dynamics of European integration in the socio-economic area, this updated neofunctionalism makes the relations among the EU member states the most important dimension. Nevertheless, students of European foreign and security policy should be aware that neofunctionalism assumes that loyalty of national officials and bureaucrats will shift to a new political centre. The spillover dynamics and the notion of unintended consequences of neofunctionalism are important elements in understanding the dynamics of the coordination of foreign and security policy among national representatives who meet regularly, and the influence on their perceptions of appropriate behaviour and common rules and principles that make joint decisions possible. The deepening of the institutional structures, the consolidation of practices, and the extension of the scope of European foreign and security policy since the early 2000s show a strong spillover dynamic. In a similar vein, Peter Haas's (1992, p. 3) work on epistemic communities shares assumptions of socialization and identity formation. Epistemic communities are defined as 'network[s] of professionals with recognized expertise in a particular domain' who share the normative and causal beliefs that link possible policy actions to desired outcomes. Haas's explanation of epistemic communities resembles the daily work of the entities involved in the coordination of EU foreign and security policy.

\section{IDENTITY, NORMS AND THE CREATION OF ACTORNESS: SOCIAL CONSTRUCTIVISM AND EUROPEAN INTEGRATION}

Social constructivism travelled from IR theory to European studies in the late 1990s. Based on a different meta-theoretical perspective, social constructivism focuses on the role that identities, norms and rules play in shaping our understanding of the world (Wendt, 1992; Katzenstein, 1996). Although not denying the importance of material conditions, scholars who draw on insights from social constructivism often turn their analytical attention to discourses, intersubjective understandings and symbolic politics to understand how the construction of social reality takes place among states and their representatives. In many ways, social constructivism has a specific affinity with European studies, and European integration as the construction of the EU depends on 
the idea of Europe, an imagined community, and a sense of shared belonging (Christiansen et al., 2001; Tonra and Christiansen, 2004). Social constructivist analyses tend to be based on one of two foundational elements: one focusing on structure, and one focusing on agency. Structure emphasizes intersubjective ideational structures such as norms, collective identities, threat perceptions and balance-of-power perceptions in the international system; whereas agency emphasizes the ability of an actor, a group or a state to explore identity formation, status and prestige, socialization and role playing.

Social constructivist perspectives were introduced into European studies during the heyday of the liberal world order and US hegemony. At the time, liberal norms and values seemed unchallenged and states around the globe appeared willing to accommodate them, as the prime protagonists were eager to oversee their spread. The thawing of relations with Russia, the eagerness of Eastern European countries to become members of the EU, and the settlement of the reunification of Germany within the confines of the European security structures, brought the conditions for the EU to develop a foreign and security policy built on actorness; that is, having the capacity to behave purposefully and act deliberately in relation to other international actors (Sjöstedt, 1977, p. 16). Social constructivists, however, adopted different approaches to the accelerating development of the EU as an international actor. These approaches primarily focus on the construction of the EU as a foreign policy actor; the international diffusion of European norms, values and principles; and the role of norms, practices and intersubjective meanings of European identity in the making of European foreign and security policy. These strands of social constructivist research on the EU are explored below.

The EU has always defied traditional definitions of its constitution: Should it be compared to a state or to an international organization? William Wallace captured the difficulty of describing the EC by calling it 'less than a federation, more than a regime' (Wallace, 1983, p. 403). Established integration theories found it even harder to conceptualize the EU as a foreign policy actor as it lacks the traditional attributes of a sovereign state, such as a standing army, stable and well-defined external borders, and a population that would recognize itself as a nation. Nonetheless, by shifting the focus from material characteristics to ideas, norms and values, social constructivist scholars explored the ideational attributes of the EU and their contribution to the construction of actorness. Accordingly, the EU has been designated a 'civilian' power (Duchêne, 1973) or an 'ethical' power (Aggestam, 2008) as it lacks military resources and does not practise traditional statecraft. In a period when the distinction between high and low politics was becoming increasingly nonsensical, the EU's soft power - that is, its ability to influence others by the force of attraction - became foundational as an explanation of its power projection (Nye, 2004; Michalski, 2005). It was, however, Ian Manners's (2002) depiction of the EU as a 'nor- 
mative power' that caught the attention not only of scholars but also of EU policy-makers. By defining its actorness in terms of the myths surroundings its inception, its hybrid polity, political-legal constitutions, as well as the norms and values written into to the founding treaties, the EU can be said to project power on the international stage to the extent that it shapes perceptions of what is considered 'normal' in international relations (Manners, 2002, p. 240). The transformative power of the EU has prompted a number of studies into the relationship between norm diffusion and identity reconstruction, as well as the theoretical and empirical boundaries of normative power Europe.

Interest in the EU's ability to diffuse norms and values beyond its borders took off in the 1990s with the eastern enlargement of the EU, and the strong conditionality exerted vis-à-vis the states in Central and Eastern Europe negotiating for EU membership. In previous enlargements, the conditionality was confined to the candidate states' adoption of the EU's body of law, adherence to its institutional structures and decision-making, and its political commitments to foreign and security policy. With the eastern enlargement of the EU, the situation was different. Not only were the candidate countries undertaking a profound transition from an authoritarian command economy to a market economy and democracy, but also the EU itself was undergoing a transformation from an economic community to a political union obligating its member states to commit to explicit liberal norms and principles. The more exacting demands were enshrined in the Copenhagen Criteria to which the Central and Eastern European countries were to comply. For social constructivist scholars, the EU's stringent conditionality attracted attention, and in particular the political dimension of the Copenhagen Criteria, which demanded the candidate states adopt institutions to preserve democratic governance, uphold human rights and protect minorities (Schimmelfennig, 2001; Schimmelfennig and Sedelmeier, 2004; Sedelmeier, 2005). The EU's decision to go ahead with the eastern enlargement, the demands put on the candidate countries, and the way in which the accession was conducted, reconfirmed the EU's status as a normative power, and the significance of norms as fundamental to community-building in Europe.

The success of the eastern enlargement strengthened the idea of the EU as a normative (super)power, and its ability to set in motion processes of socialization, norm diffusion and externalization of European policy regimes. It prompted scholars to conceptualize the influence of various instruments and methods of the EU's power beyond the confines of enlargement. Subsequently, theorizing began regarding the EU's approach to the Balkan states seeking rapprochement and membership in the EU (Björkdahl, 2012), neighbourhood policy, and relations to the states in its eastern and southern neighbourhood (Pace, 2007; Bicchi, 2007; Bremberg, 2015). In addition, the role of the EU in international politics, including its attempts to socialize even authoritarian 
states such as China to liberal norms (Michalski and Pan, 2017), became objects of study. By enacting its normative power status, the EU sought to confirm its role as a normative power in the international system, with the ambition to influence states in far-away regions such as Latin America and Africa, and shape policy, for example on the death penalty, human rights and climate change (Björkdahl et al., 2015; Scheipers and Sicurelli, 2008). Role theory, along with other social constructivist approaches, has explored the EU as a foreign policy actor in the context of a changing world order (Harnisch et al., 2011).

Unsurprisingly, the strand of social constructivism theorizing the EU as a normative power, with the ability to spread liberal norms beyond its border, is accompanied by research exploring the role of identity and adherence to European norms and values among individuals who shape European foreign and security policy. With an empirical focus on the EU, constructivist scholars, such as Jeffrey Checkel (1999, 2001, 2005), Michael Zürn and Checkel (2005), and Jeffrey Lewis (2005), have investigated the importance of the constitutive dynamics of social learning, socialization, routinization and normative diffusion in the processes that shape decisions and policy in the EU, and contrasted these with rationalist accounts of utility maximization and zero-sum calculation. These studies probe whether national representatives taking part in the decision-making processes of the EU develop a European identity, adopt the social norms of the EU and the institution in which they operate, and whether the logic of appropriateness does indeed characterize the policy-making of the EU. Theorizing such concepts entails a conceptualization of the mechanisms of socialization: the internalization of social norms; a shift of identity; and the adoption of new roles to conform to the expectations of appropriate behaviour in the group. These mechanisms give rise to socializing outcomes such as strategic calculation, role-playing and normative suasion (Checkel, 2005). Normative suasion is similar to Thomas Risse's (2000) logic of arguing, as strong internalization is understood to be connected to cognitive as well as social processes, whereas the two former, shallower forms of socialization are reminiscent of the coordination reflex discovered in studies of EU foreign and security policy (Juncos and Pomorska, 2011). Overall, studies of socialization on the micro (individual) level find that these processes are complex, given that European and national civil servants display identities embedded both in European and national contexts (Hooghe, 2005; Beyers, 2005). Moreover, shifts in identity and complete internalization of the norms and rules of supranational entities are rare, even in a highly institutionalized setting such as the EU. Nevertheless, the micro perspective of socialization offers important insights into how European foreign and security policy is coordinated and implemented, as will be further explored in Part II of this book. 
In the last decades, international practice has become a field in its own right. Although there is no unified theory of practice in social science, the 'practice turn' in IR can be said to draw on various approaches developed by scholars such as Pierre Bourdieu, Theodore Schatzki, Michael Foucault, Etienne Wenger, Bruno Latour, Ann Swidler and Luc Boltanski, to address how tacit, embodied and assumed understandings shape social interactions (Bueger and Gadinger, 2018). IR scholars who draw on practice approaches tend to focus less on whether people act on the basis of certain representations (norms, identities and logics of action), and what they do when they interact. That is, these scholars view social practices as essential to understand how phenomena of order, norms and institutions interact with individual actions, including meaning-making and constructing and organizing social knowledge (Pouliot and Cornut, 2015). Emanuel Adler and Vincent Pouliot (2011, pp. 6, 8) define practices and 'socially meaningful patterns of action' as containing both a notion of agency and intersubjectivity. Pouliot (2008, p. 258) also emphasizes that practices result from inarticulate 'practical' knowledge (that is, innate know-how) that "make[s] what is to be done appear "self-evident" or commonsensical'. The logic of practicality stems from non-reflective action from which many social and political practices derive, rather than conscious and reflective action, which has long been assumed to be a rational account of world politics and European integration.

Placing meaningful patterns of action at the centre of empirical attention has meant that many scholars who draw on practice approaches have focused on diplomacy (Pouliot and Cornut, 2015). The international diplomatic community is organized on the basis of patterned ways of interaction, codes of behaviour and language, and the lived experience of learned and embodied practices. In recent years, many studies of European diplomatic practices have revealed social practices and ways of operating that have become part of the unarticulated know-how of reproducing European foreign and security policy (Adler-Nissen, 2014a; Adler-Nissen and Pouliot, 2014; Bicchi, 2011; Bicchi and Bremberg, 2016; Bremberg, 2016b; Mérand, 2010). Chapter 4 of this book offers a more comprehensive overview of this literature, as well as a more detailed description of the main tenets of practice approaches and socialization theory.

\section{THEORIZING EUROPEAN INTEGRATION IN FOREIGN AND SECURITY POLICY}

Over time, European foreign and security policy has become an integral part of EU studies, for basically for two reasons. First, the CFSP has become an increasingly institutionalized field that opens up analysis of decision-making rules, governance and operating procedures, just as for any densely organiza- 
tional environment, along with the exploration of the role of diplomatic practices, norm internalization and socialization among officials in a transnational space of European identity formation. Second, the EU is now a recognized global actor with the capacity to influence international politics, albeit in some areas more than others. This has an impact on the political and functional dynamics of EU policy, as all of its areas of competence now have an important external dimension alongside their internal (European) dimension. The 'EU-ization' of foreign and security policy assumes that neofunctional theory is relevant to understanding the dynamics of integration and feedback loops as well as the role played by EU institutions; whereas realist perspectives focus on the formation of national interests and preferences, along with the struggle for power and influence in the shaping of European positions on the big issues of international politics and global governance.

In this book, we focus on the practices and interactions among officials from the EU institutions and member states' diplomatic corps, who at various levels and in various institutional settings and geographical locations actualize, reify and visualize EU foreign policy through their daily interaction. Chapter 4 provides a framework for studying contestations and reflexivity in communities of practice in EU foreign and security policy, as well as for studying the production of meaning and the role of socialization in sustaining European diplomacy. 